\title{
NRG3 Gene Product
}

National Cancer Institute

\section{Source}

National Cancer Institute. NRG3 Gene Product. NCI Thesaurus. Code C118417.

A protein encoded by the NRG3 gene. 